\title{
Left-handed DNA challenge
}

\author{
Juris Meija
}

(C) Crown copyright in right of Canada 2014

We would like to invite you to participate in the Analytical Challenge, a series of puzzles to entertain and challenge our readers. This special feature of "Analytical and Bioanalytical Chemistry" has established itself as a truly unique quiz series, with a new scientific puzzle published every other month. Readers can access the complete collection of published problems with their solutions on the ABC homepage at http://www.springer.com/abc. Test your knowledge and tease your wits in diverse areas of analytical and bioanalytical chemistry by viewing this collection.

In the present challenge, DNA is the topic. And please note that there is a prize to be won (a Springer book of your choice up to a value of $€ 100)$. Please read on...

\section{Meet the left-handed DNA challenge}

Both our hands can be thought of as mirror images of one another. Likewise, the DNA double helix can be drawn as two mirror images: the right-handed DNA and the left-handed DNA. Unlike our hands, however, DNA does not easily come in equal amounts of both varieties. It is the "right-handed helix" as Watson and Crick announced it in 1953 that is largely responsible for life on Earth [1] and is now often celebrated as the "Mona Lisa of modern science" [2] (Fig. 1).

Odile Crick drew the first DNA sketch for the seminal 1953 Nature paper [3] and soon thereafter Salvador Dali was among the first to depict DNA in his art. Dali got the DNA twist right

Published in the topical collection celebrating ABCs 13th Anniversary.

J. Meija $(\bowtie)$

Measurement Science and Standards, National Research Council

Canada, 1200 Montreal Road, Ottawa, ON K1A 0R6, Canada

e-mail: juris.meija@nrc.ca (literally), most prominently so in his 1957-58 Butterfly Landscape. However, the left-handed DNA is abundant among the countless depictions featuring DNA. Strictly speaking, the helicity of DNA is not always "right." Nucleotides rich with guanine and cytosine can indeed crystallize in a left-handed helix, known as the Z-DNA [4]. This left-handed DNA was in fact featured on the cover of the 13 December 1979 issue of Nature. However, the rare left-handed Z-DNA is not the intended "Mona Lisa of modern science" and most depictions of the left-handed DNA likely reflect the artistic oversight.

\section{The challenge}

The widespread occurrence of left-handed DNA images has its parallels. Representations of sharpened pencil tips or galloping horses are frequently drawn unrealistically [5]. All in all, the depictions of left-handed DNA are much like an upside-down hoisted British flag: both are widespread and many of us never even notice that something is amiss. To
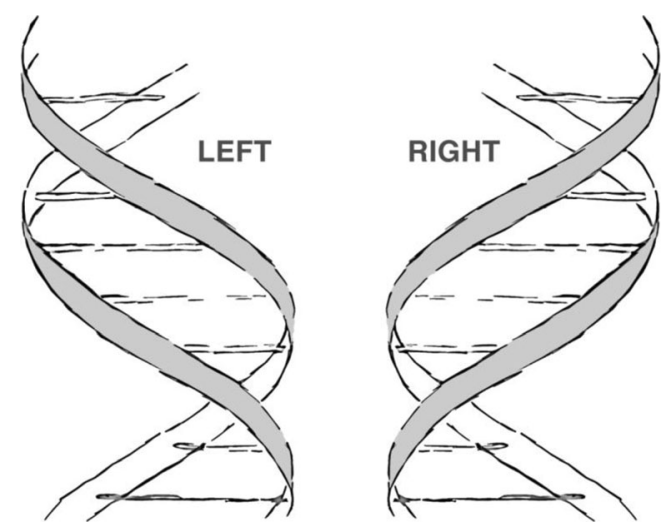

Fig. 1 Although the DNA occurs in nature almost exclusively as a righthanded helix, it can also be drawn as a left-handed helix 
those who can, in fact, spot the difference, this column invites the reader to search for the infamous left-handed DNA in unlikely places in a manner befitting the King William's College annual quiz.

Locate left-handed DNA:

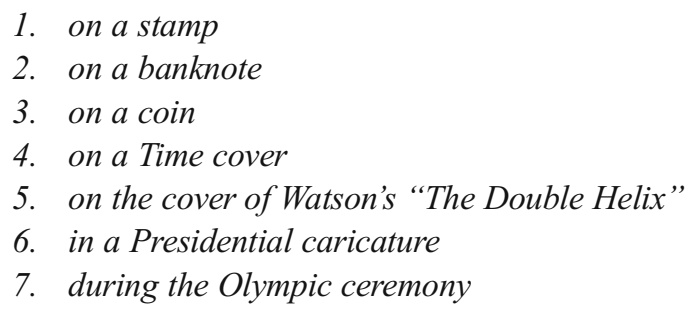

\section{References}

1. Watson JD, Crick FHC (1953) Nature 171:737-738

2. Kemp M (2004) Nature 421:416-420
3. Hevesi D (2007) New York Times, 30 July 2007

4. Wang AH, Quigley GJ, Kolpak FJ, Crawford JL, van Boom JH, van der Marel G, Rich A (1979) Nature 282:680-686

5. Petroski H (2014) Am Scientist 102:102-105

We invite our readers to participate in the Analytical Challenge by solving the puzzle above. Please send the correct solution to abc-challenge@springer.com by February 15, 2015. Make sure you enter "Left-handed DNA challenge" in the subject line of your e-mail. The winner will be notified by e-mail and his/her name will be published on the "Analytical and Bioanalytical Chemistry" homepage at http://www. springer.com/abc and in the journal (volume 407/issue12) where readers will find the solution and a short explanation.

The next Analytical Challenge will be published in 407/7, March 2015. If you have enjoyed solving this Analytical Challenge you are invited to try the previous puzzles on the $A B C$ homepage. 